\title{
Modelling reversibility of Central European mountain lakes from acidification: Part I - the Bohemian forest
}

\author{
Vladimír Majer ${ }^{1}$, Bernard J. Cosby², Jirí Kopácek³ and Josef Veselý1 \\ ${ }^{1}$ Czech Geological Survey, Geologická 6, 15200 Praha 5, Czech Republic \\ ${ }^{2}$ Department of Environmental Sciences, University of Virginia, Charlottesville, VA 22903 USA \\ ${ }^{3}$ Hydrobiological Institute, AS CR, and Faculty of Biological Sciences, USB, Na Sádkách 7, 37005 Ceské Budjovice, Czech Republic
}

Email for corresponding author: majer@cgu.cz

\begin{abstract}
A dynamic, process-based acidification model, MAGIC7, has been applied to three small, strongly acidified lakes in the Bohemian Forest, the Czech Republic. The model was calibrated for a set of experimental records on lake water composition over the 1984-2000 period, and produced hindcast concentrations that compared well, even with older (40-year) irregular determinations of nitrate, chloride and $\mathrm{pH}$. Water and soil chemistry forecasts up to 2050 were based on reductions in S and N emissions presupposed by the Gothenburg Protocol. Modelled sulphate and chloride concentrations were predicted to decrease to the levels at the beginning of the 20th century by 2050 . The lake water carbonate buffering system is predicted to be re-established in only two lakes (Cerné and Plešné), with current soil base saturations of 12$15 \%$. Concentrations of ionic aluminium species decreased sharply, from $110 \mu \mathrm{eq} 1^{-1}$ in the mid-1980s to the current $\sim 40 \mu$ eq $1^{-1}$, and were predicted to decrease below $10 \mu \mathrm{eq} 1^{-1}$ in the $2020 \mathrm{~s}$. Diatom-inferred $\mathrm{pH}$ in pre-industrial times was substantially lower than modelled $\mathrm{pH}$. It is suggested that the diatom $\mathrm{pH}$, based almost entirely on non-planktonic species, is biased by inwash of diatoms from more acidic tributaries into the sediment of these small lakes. Generally significant results can be summarised as follows: (1) Simulated sulphate levels agree well with observations during acidification progress and retreat only for values of soil $\mathrm{SO}_{4}{ }_{4}^{2-a d s o r p t i o n ~ c a p a c i t y ~ t h r e e ~ t o ~ s i x ~ t i m e s ~}(20$ to $40 \mathrm{meq}$ $\mathrm{kg}^{-1}$ ) higher than those found experimentally. This implies a further mechanism of $\mathrm{S}$ retention and release in addition to physical sulphate adsorption to Fe and Al oxides of soils. (2) The catchments' ability to retain deposited N appeared to decline after $\sim 1950$ but this was not connected with a sufficient change in the $\mathrm{C}: \mathrm{N}$ ratio of the soils. Agreement between modelled and observed concentrations of nitrate was therefore achieved by empirical restriction of $\mathrm{N}$ retention in the soils. Based on their current ability to retain $\mathrm{N}$, the catchments will remain $\mathrm{N}$ saturated and could, temporarily, produce more inorganic $\mathrm{N}$ than they receive due to additional nitrate production from soil N-organic pools. This situation has occurred already in the Cerné Lake catchment. (3) Differences in responses of individual lakes can be attributed to different land usages over the past several centuries as well as to differences in geology and primary production.
\end{abstract}

Keywords: MAGIC, atmospheric deposition, $\mathrm{N}$ retention, diatom-inferred $\mathrm{pH}$, sulphate, nitrate, base cations, aluminium, Czech Republic

\section{Introduction}

Extremely high emissions of sulphur $(\mathrm{S})$ and nitrogen $(\mathrm{N})$ compounds ( $\sim 280 \mathrm{mmol} \mathrm{m}^{-2} \mathrm{yr}^{-1}$ each) declined by $>70 \%$ and $\sim 35 \%$, respectively, in the central European region of Germany, Poland, Czech Republic and Slovakia between the second half of the 1980s and the late 1990s (Barrett et al., 2000). The reduction in atmospheric inputs of $\mathrm{S}$ and $\mathrm{N}$ to mountain ecosystems has resulted in a pronounced reversal of the acidification of fresh waters in this region (Veselý et al., 2002), including the Tatra Mountains and Bohemian Forest lakes (Kopácek et al., 1998; Veselý et al., 1998a,b). These mountain lakes responded most quickly to a decrease in $\mathrm{S}$ input and were the only European lakes exhibiting significantly decreasing trends in $\mathrm{NO}_{3}^{-}$over the 1990s (Evans et al., 2001; Prechtel et al., 2001). Despite this rapid decline in lake water concentrations of strong acid anions, their concentrations were substantially higher than expectations based on observed concentrations at comparable emission rates during the development of acidification (Kopácek et al., 2002a). This hysteresis in chemical reversal from acidification was predominantly associated with a washout of S accumulated in soils and Nsaturation of their catchments (Kopácek et al., 2001a). Consequently, mineralisation and desorption of $\mathrm{S}$ accumulated in soils and a decreasing ability of $\mathrm{N}$-saturated terrestrial ecosystems to retain $\mathrm{N}$ have become the most 
important processes affecting soil and water quality in these mountain regions, as has been observed elsewhere (e.g. Stoddard, 1994; Alewell et al., 2000).

The leaching of $\mathrm{S}$ to surface waters and the resulting changes in acid-base chemistry can be simulated with the original model of MAGIC (Modelling the Acidification of Groundwater in Catchments, Cosby et al., 1985). On the other hand, the $\mathrm{N}$ dynamics oriented model MERLIN (Model of Ecosystem Retention and Loss of Inorganic Nitrogen, Cosby et al., 1997) provides a rigorous treatment of $\mathrm{N}$ cycling. The later model, however, requires a large amount of information on $\mathrm{N}$ and $\mathrm{C}$ pools and cycles, which is usually lacking (Wright et al., 1998). The new MAGIC7 (Cosby et al., 2001) offers a satisfactory compromise between the original MAGIC and MERLIN, allowing the simulation of changes in acid-base water chemistry associated with changing $\mathrm{S}$ and $\mathrm{N}$ deposition trends (Wright et al., 1998).

The Bohemian Forest and Tatra Mountains represent unique mountain-forest and alpine ecosystems, respectively, with a high potential of lake water reversal from acidification due to the pronounced reductions in $\mathrm{S}$ and $\mathrm{N}$ deposition since the late 1980s (Kopácek et al., 2001a). In this Part I, MAGIC 7 (Cosby et al., 2001) is applied to modelling historical changes in lake water and forest soil chemistry in three catchments of the Bohemian Forest lakes and to simulating future (until 2050) responses to different scenarios of acid deposition. In Part II (Kopácek et al., 2003), a similar simulation is presented for four representative alpine catchments in the Tatra Mountains.

\section{Methods}

\section{SITE DESCRIPTION}

In the Bohemian Forest at the Czech-German-Austrian border, there are eight small glacial lakes situated between $48^{\circ} 47^{\prime}$ and $49^{\circ} 11^{\prime} \mathrm{N}$, and $13^{\circ} 07^{\prime}$ and $13^{\circ} 52^{\prime} \mathrm{E}$, at elevations of 918-1096 m a.s.l. The following three lakes were included in this study: (1) Cerné Lake (CN), the largest; (2) Certovo Lake (CT), the most acid; and (3) Plešné Lake (PL), with the highest trophic status due to a higher loading of phosphorus (P) and dissolved organic carbon from natural terrestrial sources than in other lakes. The selected lakes are dimictic, drainage, oligotrophic (CN and CT) or mesotrophic (PL) water bodies, with theoretical water residence times between 0.7 and 1.6 years and with three to nine surface tributaries (Kopácek et al., 2001b,c,d).

CT and CN Lakes are situated on opposite sides of the same mountain and their catchments are steep with maximum local reliefs of $313 \mathrm{~m}$ and $335 \mathrm{~m}$, respectively.
The bedrock is formed primarily of mica-schist (muscovitic gneiss) in the $\mathrm{CN}$ catchment, and mica-schist with quartzite intrusions in the CT catchment (Veselý, 1994). The PL catchment has a maximum local relief of $288 \mathrm{~m}$ and its bedrock is formed of granite. All three catchments were covered with local glaciers during the last glacial period (Veselý, 1994). More than $90 \%$ of the catchments have 90-160 years old forest cover, dominated by Norway spruce, with a minor contribution of mountain-ash and beech. For more morphological details on the lakes and their catchments see Table 1 and Veselý (1994).

\section{SOIL CHEMISTRY}

Soil samples were taken from all major organic and mineral horizons at sites representative for particular parts of the CT, CN, and PL catchments $(11,8$, and 12 soil profiles, respectively) between September 1997 and May 2001. More details on heterogeneity in the soil distribution were obtained by grid samplings in regular $50 \times 50 \mathrm{~m}(\mathrm{PL})$ and $75 \times 75 \mathrm{~m}$ (CT) grids. The vertical and spatial heterogeneity of soil properties within a soil profile and across the whole catchment, respectively, was 'homogenised' numerically to provide a catchment weighted mean (CWM) composition. This catchment weighting generates a single value for each parameter, representing a hypothetical situation in which all soils are uniformly distributed over the whole catchment. The physical and chemical characteristics of soils in the lake catchments were determined as described in detail by Kopácek et al. (2002b,c).

The CT catchment was found to be covered predominantly with $\sim 0.5 \mathrm{~m}$ deep spodo-dystric cambisol ( $58 \%$ of area) and podzol ( $21 \%$ of area), and shallow ( $\sim 0.2 \mathrm{~m})$ undeveloped organic rich soil (17\% of area). Wetland covered $<3 \%$ of the CT catchment area. The dominant contribution of spododystric cambisol and podzol, and negligible wetland areas were also evident in the $\mathrm{CN}$ catchment. The PL catchment area was covered with an undeveloped $\sim 0.2 \mathrm{~m}$ deep organic rich soil ( $38 \%$ of area), and $\sim 0.45 \mathrm{~m}$ deep podzol ( $29 \%$ of area) or spodo-dystric cambisol (27\% of area). Wetland and bare rocks covered $1 \%$ and $5 \%$ of the catchment area, respectively.

Fine soil was sandy, with a low (1-4\%) content of clay, and CWM soil pools were 225,143 , and $92 \mathrm{~kg} \mathrm{~m}^{-2}$ in the CT, CN, PL catchments, respectively. Soil pH was generally low, with the lowest $\mathrm{pH}_{\mathrm{CaCl} 2}$ values (2.5-3.3) in the humus horizon. The CWM cation exchange capacity of the CT and CN soils was 104 and 123 meq $\mathrm{kg}^{-1}$, respectively, and was dominated by exchangeable $\mathrm{Al}^{3+}$ (62\% and 55\%). The CWM base saturation of the CT and CN soils was $9 \%$ and $15 \%$, respectively. It was primarily based on exchangeable $\mathrm{Ca}^{2+}$ 
Table 1. Major morphological characteristics and measured or estimated soil parameters for the Bohemian Forest lakes (Kopácek et al., 2001b,c,d) and their catchments (Kopácek et al., 2002b,c; Kana, personal communication).

\begin{tabular}{|c|c|c|c|c|}
\hline \multirow[b]{2}{*}{ Parameter } & \multirow[t]{2}{*}{ Units } & \multirow[b]{2}{*}{ Cerné } & \multicolumn{2}{|l|}{ Lake } \\
\hline & & & Certovo & PleŠNÉ \\
\hline \multicolumn{5}{|l|}{ Morphology } \\
\hline Latitude (N) & & $49^{\circ} 11^{\prime}$ & $49^{\circ} 10^{\prime}$ & $48^{\circ} 47^{\prime}$ \\
\hline Longitude (E) & & $13^{\circ} 11^{\prime}$ & $13^{\circ} 12^{\prime}$ & $13^{\circ} 52^{\prime}$ \\
\hline Water level elevation & $\mathrm{m}$ & 1008 & 1028 & 1090 \\
\hline Lake volume & $10^{6} \mathrm{~m}^{3}$ & 2.88 & 1.85 & 0.62 \\
\hline Maximum depth & $\mathrm{m}$ & 40 & 36 & 18 \\
\hline Lake area & ha & 18.4 & 10.3 & 7.5 \\
\hline Retention time & $\mathrm{yr}$ & 1.63 & 1.58 & 0.73 \\
\hline Catchment area (including lake) & ha & 129 & 86 & 67 \\
\hline \multicolumn{5}{|l|}{ Soil Parameters } \\
\hline Soil depth & $\mathrm{m}$ & 0.53 & 0.65 & 0.33 \\
\hline Porosity ${ }^{1)}$ & $\%$ & 50 & 50 & 50 \\
\hline Bulk density & $\mathrm{kg} \mathrm{m}^{-3}$ & 269 & 345 & 281 \\
\hline Fine soil pool & $\mathrm{kg} \mathrm{m}^{-2}$ & 143 & 225 & 92 \\
\hline Cation exchange capacity & meq kg-1 & 125 & 106 & 130 \\
\hline Ca saturation & $\%$ & 6.6 & 4.3 & 8.8 \\
\hline $\mathrm{Mg}$ saturation & $\%$ & 2.6 & 1.8 & 2.3 \\
\hline Na saturation & $\%$ & 1.1 & 1.0 & 2.2 \\
\hline $\mathrm{K}$ saturation & $\%$ & 2.2 & 2.1 & 1.9 \\
\hline Used $\mathrm{SO}_{4}$ ads. half-saturation ${ }^{1)}$ & meq $\mathrm{m}^{-3}$ & 100 & 100 & 100 \\
\hline Measured $\mathrm{SO}_{4}$ ads. max-capacity & meq kg ${ }^{-1}$ & 12 & 6.4 & 6.0 \\
\hline Used $\mathrm{SO}_{4}$ ads. max-capacity ${ }^{1}$ & meq $\mathrm{kg}^{-1}$ & 40 & 20 & 40 \\
\hline Total organic acid ${ }^{2)}$ & $\mathrm{mmol} \mathrm{m}^{-3}$ & 85 & 85 & 85 \\
\hline C pool & $\mathrm{mol} \mathrm{m} \mathrm{m}^{-2}$ & 1120 & 1350 & 936 \\
\hline $\mathrm{N}$ pool & $\mathrm{mol} \mathrm{m} \mathrm{m}^{-2}$ & 50 & 59 & 39 \\
\hline Average $\mathrm{C}: \mathrm{N}$ of soil profile & $\mathrm{mol} \mathrm{mol}^{-1}$ & 22 & 23 & 24 \\
\hline \multicolumn{5}{|l|}{ In-lake sedimentation velocity } \\
\hline $\mathrm{Ca}$ & $\mathrm{m} \mathrm{yr}^{-1}$ & 0.09 & 0.18 & 0.32 \\
\hline $\mathrm{Mg}$ & $\mathrm{m} \mathrm{yr}^{-1}$ & 0.09 & 0.33 & 0.37 \\
\hline $\mathrm{N}$ & $\mathrm{m} \mathrm{yr}^{-1}$ & 1.37 & 2.02 & 6.80 \\
\hline
\end{tabular}

$(\sim 50 \%)$, and the contribution of $\mathrm{Mg}^{2+}$ and $\mathrm{K}^{+}$was roughly equal ( $20 \%)$. The CWM cation exchange capacity of the PL soils was 129 meq $\mathrm{g}^{-1}, 15 \%$ of which was base saturated, and was dominated by exchangeable $\mathrm{Al}^{3+}(57 \%)$ and protons (28\%). The CWM carbon to nitrogen $(\mathrm{C}: \mathrm{N})$ ratio was 23 , 22, and 24 for the whole CT, CN, and PL soil profiles, respectively, and varied between 23 and 33 in the forest floor. The CWM pools of C and $\mathrm{N}$ are given in Table 1.

The $\mathrm{SO}_{4}{ }^{2-}$ sorption characteristics of catchment soils were determined in batch experiments according to Alewell
(1998). Sorption experiments were conducted with fresh samples at the original soil $\mathrm{pH}$ in the sulphate concentration range of $0-100 \mu \mathrm{mol} \mathrm{l}^{-1}$.

\section{LAKE WATER CHEMISTRY}

The historical data (before 1984) on lake water concentrations come from Jírovec and Jírovcová (1937), Veselý (1994), and Procházková and Blažka (1999) and have been found to be reasonably reliable (Veselý and Majer, 
1992; Procházková and Blažka, 1999). Lake water concentrations in the 1984-2001 period are from a regular monitoring programme (Veselý et al., 1998a,b; unpublished data). Data on terrestrial and in-lake sources and sinks of elements were based on their mass budgets in the 2000 hydrological year (Kopácek et al., $2001 \mathrm{~b}, \mathrm{c}, \mathrm{d}$ ). The concentration of organic acid anions ( $\left.\mathrm{A}^{\prime}\right)$ in lake water was assumed to be proportional to DOC (42 meq per mol of DOC; Kopácek, unpublished data). Since 1984, concentrations of total aluminium $\left(\mathrm{Al}_{\mathrm{T}}\right)$ were determined by inductively coupled plasma atomic emission spectrometry. In parallel, Al fractionation according to Driscoll (1984) has been analysed in a filtrate $(<0.4 \mu \mathrm{m}$ pore size) regularly since 1993 to determine the proportion of dissolved inorganic $\mathrm{Al}\left(\mathrm{Al}_{\mathrm{i}}\right)$, organically bound $\mathrm{Al}\left(\mathrm{Al}_{\mathrm{o}}\right)$, and particulate $(>0.4 \mu \mathrm{m}) \mathrm{Al}\left(\mathrm{Al}_{\text {part }}\right)$ in the total $\mathrm{Al}$ pool. Equivalent concentrations of $\mathrm{Al}_{\mathrm{i}}\left(\mathrm{Al}_{\mathrm{i}}{ }^{\mathrm{n}+}\right)$ were obtained from their molar concentrations and the average charge of $\mathrm{Al}$ hydroxocomplexes $(n)$ at the sample $\mathrm{pH}$ (Stumm and Morgan, 1981). In-lake concentrations of $\mathrm{Al}_{\mathrm{i}}$ before 1993 were estimated from the measured $\mathrm{Al}_{\mathrm{T}}$ concentrations, assuming a similar $\mathrm{Al}_{\mathrm{T}}: \mathrm{Al}_{\mathrm{i}}$ ratio as observed after 1993. These $\mathrm{Al}_{\mathrm{T}}: \mathrm{Al}_{\mathrm{i}}$ ratios were $1.04,1.14$, and 1.28 for $\mathrm{CT}, \mathrm{CN}$, and PL Lake, respectively. The $\mathrm{Al}_{\mathrm{i}}^{\mathrm{n}+}$ concentrations before 1993 come from: 1984, Veselý et al. (1998b); and 19881989, Fott et al. (1994).

\section{ATMOSPHERIC DEPOSITION}

The 1860-2000 trends in bulk and throughfall deposition of $\mathrm{SO}_{4}{ }^{2-}, \mathrm{NH}_{4}^{+}$, and $\mathrm{NO}_{3}{ }^{-}$come from Kopácek et al. (2001a).
The respective trends in the $\mathrm{Cl}^{-}$deposition were assumed to be proportional to the deposition of $\mathrm{S}$, with the $\mathrm{S}: \mathrm{Cl}$ ratios obtained for the bulk and throughfall deposition in the catchments studied. The trend in the bulk deposition of BC was based on (1) relationships between $\mathrm{BC}$ concentrations in precipitation in the Bohemian Forest (Hruška et al., 2000; Kopácek, unpublished data) and at long-term monitored sites in the Czech Republic, and (2) the emission rate of particulates from Czech industrial sources, taken from Yearbooks of the Czech Statistical Office (data after 1980) and was assumed to be proportional to the $\mathrm{S}$ emission before 1980. Then, the deposition trend of BC was calculated as the sum of background $\mathrm{BC}$ deposition (originating from agricultural sources) plus industrial $\mathrm{BC}$ deposition. The background bulk deposition of BC $\left(\sim 25 \mathrm{meq} \mathrm{m}^{-2} \mathrm{yr}^{-1}\right)$ was estimated by extrapolating the relationship between bulk $\mathrm{BC}$ and $\mathrm{S}$ depositions (for the 1985-2000 period) to the $\mathrm{S}$ deposition equalling zero.

Throughfall deposition of $\mathrm{Ca}^{2+}, \mathrm{Mg}^{2+} \mathrm{K}^{+}$, and $\mathrm{NH}_{4}^{+}$is usually affected strongly by canopy processes (e.g. Lovett, 1992; Dise et al., 1998). In the Bohemian Forest, the average ratio between concentrations of conservative ions $\left(\mathrm{SO}_{4}{ }^{2-}\right.$, $\mathrm{Cl}^{-}$, and $\mathrm{Na}^{+}$) in throughfall and bulk deposition was $\sim 1.7$ in the 1997-2000 period (Kopácek et al., 2001b). This ratio was used to estimate the proportion of dry deposition of $\mathrm{Ca}^{2+}, \mathrm{Mg}^{2+}$ and $\mathrm{K}^{+}$ions, concentrations of which were increased in throughfall by canopy leaching. The same approach was used to estimate dry deposition of $\mathrm{NH}_{4}^{+}$, which was negatively affected by canopy interactions (its concentration was only $20 \%$ higher in throughfall than in bulk samples). Consequently, atmospheric inputs of BC and
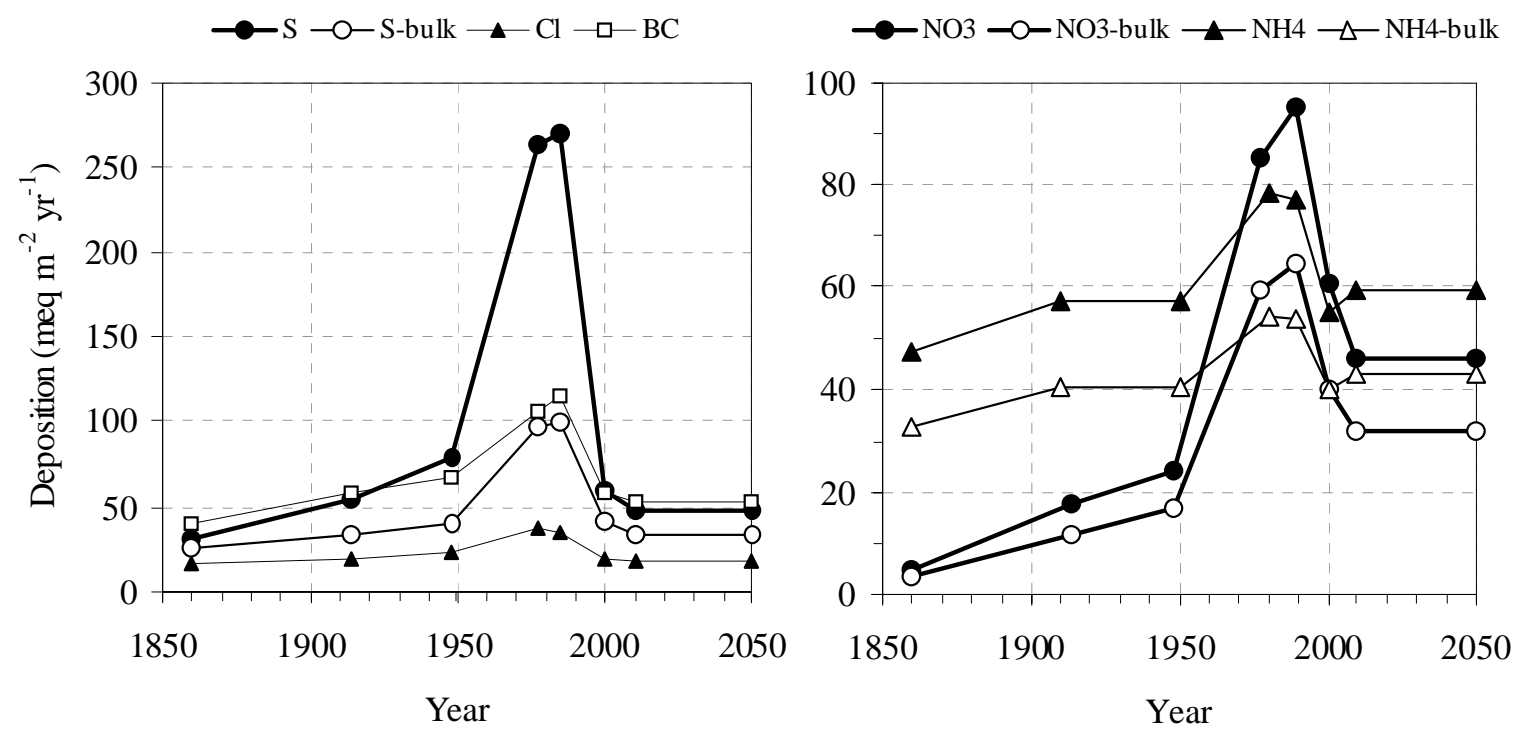

Fig. 1. Long-term trend in total (and bulk $\mathrm{SO}_{4}-\mathrm{S}$ and $\mathrm{NO}_{3}-\mathrm{N}$ ) atmospheric deposition of major ions in the catchments of the Bohemian Forest used for MAGIC modelling. 
$\mathrm{NH}_{4}^{+}$into the forested parts of catchments were assumed to be 1.7-fold higher than bulk deposition and this constant was used for the whole 1860-2000 period.

Two scenarios of element deposition were used for future (2000-2050) predictions: (1) Constant trends at 2000 deposition levels and (2) decreasing deposition until 2010 and then constant until 2050. The decrease in deposition of $\mathrm{S}$ and $\mathrm{N}$ compounds from 2000 to 2010 was assumed to be proportional to the decrease in their respective emission levels in the central European region (Germany, Poland, Czech Republic, and Slovakia) as required by the Gothenburg Protocol (UN-ECE, 1999). This simplified approach was used because atmospheric deposition of $\mathrm{S}$ and $\mathrm{N}$ compounds in central Europe originates predominantly (65\% to $85 \%$ ) from emissions within the region (Berge, 1997). The future changes in the $\mathrm{Cl}^{-}$and $\mathrm{BC}$ deposition were assumed to be proportional to changes in $\mathrm{S}$ deposition.

Total chemical input into the catchment-lake ecosystem of the Bohemian Forest lakes from atmospheric sources was calculated from the estimated trends in throughfall and bulk deposition onto the respective areas of forest and bare surface (including the lake). This input was assumed to be roughly equal for all three lakes studied, because the morphological parameters of their catchments (Table 1), as well as precipitation chemistry at CT and PL Lakes (Kopácek et al., 2001b,d), were similar. The resulting trends in total atmospheric input of $\mathrm{SO}_{4}{ }^{2-}, \mathrm{NO}_{3}^{-}, \mathrm{NH}_{4}^{+}, \mathrm{Cl}^{-}$, and $\mathrm{BC}$, including their decrease according to the Gothenburg Protocol, are given in Fig. 1.

The average annual precipitation height and runoff was assumed to be 1.50 and $1.35 \mathrm{~m}$, respectively, constant over the 1860-2050 period. These values were based on (1) the average throughfall deposition in the CT catchment in the 1992-2001 period, (2) long-term (1961-2001) precipitation in the central part of the Bohemian Forest (Churánov station, $49^{\circ} 04^{\prime} \mathrm{N} ; 13^{\circ} 37^{\prime} \mathrm{E} ; 1122 \mathrm{~m}$ a.s.1.), and (3) water balance (evaporation) calculated for the catchment-lake ecosystems studied (Kopácek et al., 2000, 2001b,c,d).

\section{Results and discussion}

\section{MODEL CALIBRATION}

The MAGIC (version 7) model by Cosby et al. (2001) was calibrated using measured deposition, long-term data on lake water chemistry from 1984 to 2000, and soil composition for the year 2000 (Table 1). The fixed parameters (Table 2) were selected or set empirically and calibrations at each site proceeded by the following sequential steps:

(1) Trends in the total deposition of $\mathrm{SO}_{4}^{2-}, \mathrm{Cl}^{-}, \mathrm{NO}_{3}^{-}, \mathrm{NH}_{4}^{+}$, and $\mathrm{BC}$ into the catchments were applied as shown in Fig. 1. At the beginning of the Industrial Revolution, reduced nitrogen compounds dominated the sum of emitted and deposited $\mathrm{S}$ and $\mathrm{N}$ compounds in central Europe. Atmospheric inputs of $\mathrm{SO}_{4}{ }^{2-}$ and $\mathrm{NO}_{3}{ }^{-}$increased steadily until the late 1950s and then, very sharply (3 to 4 -fold) between the 1950s and 1980s to $\sim 270$ and $\sim 95 \mathrm{meq} \mathrm{m}^{-2} \mathrm{yr}^{-1}$, respectively. The increase in $\mathrm{NH}_{4}^{+}$ deposition was less than that of $\mathrm{NO}_{3}^{-}$, which led to a change in deposition quality of dissolved inorganic nitrogen $\left(\mathrm{DIN}=\mathrm{NO}_{3}-\mathrm{N}+\mathrm{NH}_{4}-\mathrm{N}\right.$ ) from that dominated by $\mathrm{NH}_{4}-\mathrm{N}$ to $\mathrm{NO}_{3}-\mathrm{N}$ domination since the 1960 s (Fig. 1). Hence, the total DIN deposition and its $\mathrm{NO}_{3}-\mathrm{N}: \mathrm{NH}_{4}-\mathrm{N}$ ratio increased 2 and 3-fold, respectively, between the 1950s and 1980s.

In the 1990s, atmospheric inputs of S and DIN decreased by $80 \%$ and $\sim 30 \%$ to 60 and $\sim 110$ meq $\mathrm{m}^{-2} \mathrm{yr}^{-1}$, respectively, in the Bohemian Forest. Due to this rapid decline, the 2010 target emissions of $\mathrm{S}$ and $\mathrm{N}$ compounds (Gothenburg Protocol; UN-ECE, 1999) were nearly reached in central Europe by the late 1990s, and only small additional decreases can be expected for $\mathrm{SO}_{4}{ }^{2-}$ and $\mathrm{NO}_{3}{ }^{-}$deposition (Fig. 1). In contrast, the current emission rate of $\mathrm{NH}_{3}$ in central Europe is lower than the 2010 target and the future scenario of $\mathrm{NH}_{4}^{+}$ deposition is a slight increase. Around 2010, the $\mathrm{SO}_{4}^{2-}, \mathrm{NH}_{4}^{+}$, and $\mathrm{NO}_{3}^{-}$deposition in the Bohemian Forest will reach levels comparable to those in the

Table 2. Fixed parameters (measured* or estimated) for the Bohemian Forest lakes and catchment soils used in calibration of MAGIC 7.

\begin{tabular}{|c|c|c|c|}
\hline Parameter & $\begin{array}{c}\text { For water } \\
\text { or soil }\end{array}$ & Units & All lakes \\
\hline Precipitation height* & & $\mathrm{m}$ & 1.50 \\
\hline Annual discharge* & & $\mathrm{m}$ & 1.35 \\
\hline \multirow[t]{2}{*}{ Temperature* } & water & ${ }^{\circ} \mathrm{C}$ & $5.6-6.0$ \\
\hline & soil & ${ }^{\circ} \mathrm{C}$ & 4.5 \\
\hline \multirow[t]{2}{*}{$\mathrm{CO}_{2}$ partial pressure } & water & atm & 0.0005 \\
\hline & soil & atm & 0.0045 \\
\hline $\mathrm{pK}_{1}$ (organic acids) & soil and water & $-\log$ & 2.6 \\
\hline $\mathrm{pK}_{2}$ (organic acids) & soil & $-\log$ & 5.66 \\
\hline $\mathrm{pK}_{2}$ (organic acids) & water & $-\log$ & 5.8 \\
\hline $\mathrm{pK}_{3}$ (organic acids) & soil & $-\log$ & 5.94 \\
\hline $\mathrm{pK}_{3}$ (organic acids) & water & $-\log$ & 7.0 \\
\hline Solubility $\mathrm{Al}(\mathrm{OH})_{3}$ & soil and water & $\log$ & 9.0 \\
\hline $\mathrm{K}(\mathrm{AlA})$ & water & Log & 8.5 \\
\hline $\mathrm{K}\left(\mathrm{AlHA}^{+}\right)$ & water & $\log$ & 10.0 \\
\hline
\end{tabular}


$1890 \mathrm{~s}$, the first half of the $20^{\text {th }}$ century, and the $1950 \mathrm{~s}$, respectively (Fig. 1).

(2) Net annual retention of $\mathrm{Ca}, \mathrm{Mg}$, and $\mathrm{N}$ in the lakes (Table 1) was estimated from their concentrations in surface sediments and sedimentation rates (Kopácek et al., $2001 \mathrm{~b}, \mathrm{c}, \mathrm{d})$, and were held constant for the whole period.

(3) The measured $\mathrm{SO}_{4}{ }^{2-}$ adsorption half saturation and maximum adsorption capacity varied from 2000 to 2200 meq $\mathrm{m}^{-3}$ and from 6 to $12 \mathrm{meq} \mathrm{kg}^{-1}$, respectively (Kana, personal communication). These adsorption maxima were too low for the model to predict properly the observed delay between $\mathrm{SO}_{4}{ }^{2-}$ deposition and in-lake concentrations during both the acidification advance and retreat. Consequently, in the calibration procedure, soil sulphate chemistry (as well as other ions) was fitted such that modelled concentration equalled the measured concentration in lake water during the 1984-2000 period. The fitted values of $\mathrm{SO}_{4}{ }^{2-}$ maximum adsorption capacity, which simulated, reasonably, the observed trends in lake water chemistry, were 3 to 6 -fold higher than the measured adsorption data $\left(20--40\right.$ meq $\left.\mathrm{kg}^{-1}\right)$. This pattern suggests other effective mechanisms immobilising $\mathrm{S}$ in the forest floor organic matter (Novák et al., 1996; Torssander and Mörth, 1998) or in basic aluminium sulphates (Nordstrom, 1982), which paralleled the physical adsorption of $\mathrm{SO}_{4}{ }^{2-}$ on $\mathrm{Fe}$ and Al oxides.

The measured in-lake reduction of $\mathrm{SO}_{4}{ }^{2-}$ varied between 143 and $214 \mathrm{meq} \mathrm{m}^{-2} \mathrm{yr}^{-1}$ (on a lake surface area basis), representing $13 \%$ of the total (terrestrial and atmospheric) $\mathrm{SO}_{4}^{2-}$ input in CT and PL Lakes and $22 \%$ in CN Lake in 2000 (Kopácek et al., 2001b,c,d). These values were too high to model the $\mathrm{SO}_{4}{ }^{2-}$ concentration maxima in the 1980 s satisfactorily. Alternatively, a $\sim 5 \%$ in-lake reduction of $\mathrm{SO}_{4}{ }^{2-}$ was estimated from $\mathrm{SO}_{4}{ }^{2-}$ loading and mass transfer coefficient of $0.54 \mathrm{~m} \mathrm{yr}^{-1}$ according to Kelly et al. (1987). The best agreement between the measured and simulated concentrations was obtained with a $5 \%$ inlake reduction of $\mathrm{SO}_{4}^{2-}$ in PL and CT Lakes and a 20\% reduction in $\mathrm{CN}$ Lake. The lower in-lake reduction of $\mathrm{SO}_{4}^{2-}$ (both measured and simulated) in PL and CT Lakes was due to anoxic conditions in their hypolimnion. Sulphate reduction in the sediment is the most effective in-lake sink of $\mathrm{SO}_{4}{ }^{2-}$ when water above the sediment is under oxic conditions (Kelly and Rudd, 1984). Under anoxia, sulphate concentrations decreased above the bottom of CT and PL Lakes (Kopácek et al., $2001 \mathrm{~b}, \mathrm{~d}$ ), which limited the $\mathrm{SO}_{4}{ }^{2-}$ diffusion into sediments and, consequently, its more effective reduction.

(4) Nitrogen leaching to surface water depends on the difference between $\mathrm{N}$-input via deposition and its uptake by plants, denitrification loss, and net immobilisation in the soil (Cosby et al., 2001). Net immobilisation of $\mathrm{N}$ in the soil is assumed to be governed in the model by the $\mathrm{C}: \mathrm{N}$ ratio. The estimated relatively small change in the soil C:N ratios from $\sim 25$ to $22-24$ in the 1930-2000 period (Kopácek et al., 2001a), however, did not allow the model to simulate the observed dramatic changes in lake water $\mathrm{NO}_{3}{ }^{-}$concentrations. There are no data available to evaluate historical changes in the ability of terrestrial parts of the Bohemian Forest catchment-lake ecosystems to immobilise or lose $\mathrm{N}$ (e.g. changes in plant uptake of $\mathrm{N}$ or mineralisation rate of soil organic $\mathrm{N}$ pools). Hence, net retention of DIN in the catchment was set empirically such that modelled $\mathrm{NO}_{3}{ }^{-}$concentrations equalled the measured concentrations throughout the study period (Fig. 2). For the 2000-2050 period, the net $\mathrm{N}$ retention in the catchment was assumed to be the same as in 2000 .

(5) Weathering rates, cation-exchange selectivity coefficients for base cations, and the original base saturation of soils were determined by a trial-and-error procedure such that the modelled pools and

Table 3. Calibrated parameters for the Bohemian Forest lakes obtained from MAGIC 7.

\begin{tabular}{|c|c|c|c|c|}
\hline & \multirow[t]{2}{*}{ Units } & \multicolumn{3}{|c|}{ Lake } \\
\hline & & CERnÉ & Certovo & PleŠNÉ \\
\hline \multicolumn{5}{|c|}{ Cation exchange selectivity coefficients } \\
\hline $\mathrm{Al}-\mathrm{Ca}$ & $\log$ & -1.82 & -1.87 & -1.68 \\
\hline $\mathrm{Al}-\mathrm{Mg}$ & $\log$ & -0.57 & -0.53 & -1.09 \\
\hline $\mathrm{Al}-\mathrm{Na}$ & $\log$ & -3.37 & -3.66 & -3.81 \\
\hline Al-K & $\log$ & -5.43 & -5.68 & -5.28 \\
\hline \multicolumn{5}{|c|}{ Weathering rates } \\
\hline $\mathrm{Ca}^{2+}$ & meq $\mathrm{m}^{-2} \mathrm{yr}^{-1}$ & 16.0 & 1.8 & 33.2 \\
\hline $\mathrm{Mg}^{2+}$ & meq $\mathrm{m}^{-2} \mathrm{yr}^{-1}$ & 41.5 & 32.4 & 18.2 \\
\hline $\mathrm{Na}^{+}$ & meq $\mathrm{m}^{-2} \mathrm{yr}^{-1}$ & 12.0 & 2.1 & 21.4 \\
\hline $\mathrm{K}^{+}$ & meq $\mathrm{m}^{-2} \mathrm{yr}^{-1}$ & 2.0 & 0.0 & 1.3 \\
\hline \multicolumn{5}{|c|}{ Initial base saturation (1860) } \\
\hline $\mathrm{Ca}$ & $\%$ & 11.9 & 5.4 & 17.4 \\
\hline $\mathrm{Mg}$ & $\%$ & 6.0 & 3.4 & 4.9 \\
\hline $\mathrm{Na}$ & $\%$ & 1.4 & 1.0 & 2.7 \\
\hline K & $\%$ & 2.2 & 1.8 & 1.9 \\
\hline
\end{tabular}




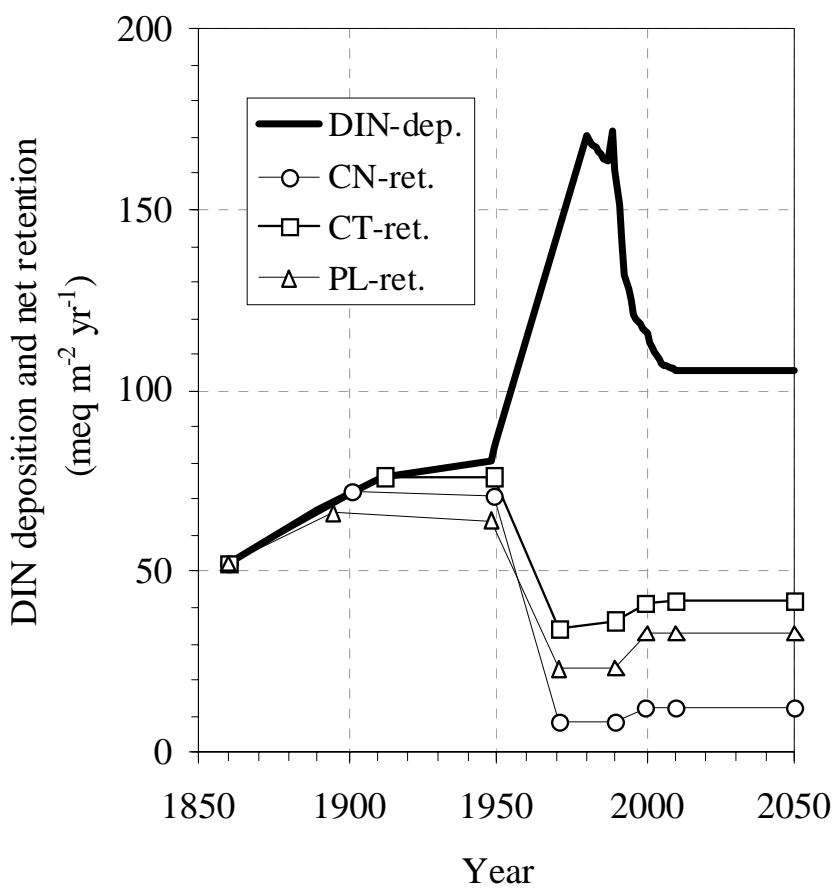

Fig. 2. Trends in atmospheric deposition of dissolved inorganic nitrogen $\left(\mathrm{NO}_{3}-\mathrm{N}+\mathrm{NH}_{4}-\mathrm{N} ; \mathrm{DIN}\right.$-dep.) and the assumed DIN retention in the catchments of Cerné, Certovo, and Plešné Lakes (CN-ret., CT-ret., and PL-ret., respectively).

concentrations equalled the measured soil exchange pools and lake chemistry concentrations of each base cation for the year 2000. This step was performed using an automated optimisation routine and the results are given in Table 3. Because the vegetation uptake of BC was set equal to zero in the optimisation, the resulting weathering rates represented a net difference between the $\mathrm{BC}$ supply by the real weathering processes and the $\mathrm{BC}$ sink by vegetation uptake.

(6) Fixed parameters (Table 2): Dissociation constants of tri-protic organic acids and $\mathrm{Al}(\mathrm{OH})_{3}$ solubility were selected within widely used ranges (e.g. Sullivan et al., 1996; Wright et al., 1998) and further fitted in the MAGIC calibration procedure. Stability constants of organic-Al complexes $\left(\mathrm{K}(\mathrm{AlA})\right.$ and $\mathrm{K}\left(\mathrm{AlHA}^{+}\right)$) were set empirically within the set of published data (e.g. Browne and Driscoll, 1993; Nordstrom and Howard, 1996), such that the modelled concentrations equalled the measured concentrations of $\mathrm{Al}_{\mathrm{i}}^{\mathrm{n}+}$ and $\mathrm{Al}_{\mathrm{o}}$ in lake water. Concentrations of $\mathrm{A}^{-}$were adjusted by optimising the $\mathrm{pK}$ values of the tri-protic organic acid such that modelled concentrations equalled the measured concentrations.

\section{MODELLING OF NITROGEN DYNAMICS}

The observed lake water concentrations of $\mathrm{NO}_{3}{ }^{-}$in 1936 were below the detection limit of the analytical method used at the time $\left(<2 \mu\right.$ eq $\left.1^{-1}\right)$ (Jírovec and Jírovcová, 1937; Veselý and Majer, 1992). The elevated $\mathrm{NO}_{3}{ }^{-}$concentrations in the beginning of 1960s (Procházková and Blažka, 1999) were determined by a more reliable method, based on the colorimetric determination of $\mathrm{NO}_{2}{ }^{-}$after $\mathrm{NO}_{3}{ }^{-}$reduction with alkaline hydrazine (Procházková, 1959). The changes in these values suggest that catchments of the Bohemian Forest lakes started to leach $\mathrm{NO}_{3}^{-}$between the 1930s and the late $1950 \mathrm{~s}$, in the period of sharp increase in $\mathrm{NO}_{3}{ }^{-}$deposition (Fig. 1). Consequently, the net retention of DIN was set equal to its deposition in the $1860-1900$ period and slightly lower than its deposition (to fit the observations from the 1930s) in the 1900-1950 period (Figs. 2 and 3). For these two periods, it was assumed that the terrestrial ecosystem was adapted to a relatively high and stable $\mathrm{NH}_{4}^{+}$deposition, for more than a hundred years before the 1950s (Fig. 1). The hypothesis is that the terrestrial ecosystems were Nlimited or in steady state conditions in respect of DIN deposition, which was dominated by $\mathrm{NH}_{4}^{+}$and around the empirical threshold of $10 \mathrm{~kg} \mathrm{ha}^{-1} \mathrm{yr}^{-1}$, below which $\mathrm{NO}_{3}^{-}$ leaching from European forest soils is usually low (e.g. Dise et al., 1998).

The catchments studied were unable to retain and assimilate the rapidly increasing $\mathrm{NO}_{3}^{-}$input already present in 1960s, which resulted in the elevated terrestrial export of $\mathrm{NO}_{3}{ }^{-}$(Fig. 3). This change was probably not associated with any significant change in the soil C:N ratios (Kopácek et al., 2001a) and more likely reflected a simple dose-response function. Nitrate is a more mobile ion than $\mathrm{NH}_{4}^{+}$and its relatively short residence time in the catchments studied (shallow soils and steep terrain) probably disables its assimilation. However, the decreasing ability of the catchments to assimilate $\mathrm{N}$ (Kopácek et al., 2002a) suggests that this simple dose-response function changed with time. While the ecosystems assimilated $\sim 70 \mathrm{meq} \mathrm{m}^{-2} \mathrm{yr}^{-1}$ of DIN at the beginning of 20th century, the DIN assimilation was substantially lower $\left(<20 \mathrm{meq} \mathrm{m}^{-2} \mathrm{yr}^{-1}\right)$ in the late $1990 \mathrm{~s}$. The PL catchment still assimilated $\sim 16 \%$ of the deposited DIN but the CT catchment exported nearly all deposited DIN, and the CN catchment produced $28 \%$ more DIN than it received by atmospheric input (Kopácek et al., 2001b,c,d). This suggests that the net terrestrial production of $\mathrm{NO}_{3}{ }^{-}$was higher than the retention of atmospheric $\mathrm{NH}_{4}^{+}$in the $\mathrm{CN}$ catchment, probably due to additional $\mathrm{NO}_{3}-$ production from the pool of soil organic N.

In the model, it is assumed that the elevated deposition of $\mathrm{NO}_{3}{ }^{-}$after the 1950s (Fig. 1) led to a gradual transition of 
Modelling reversibility of Central European mountain lakes from acidification: Part I - the Bohemian forest
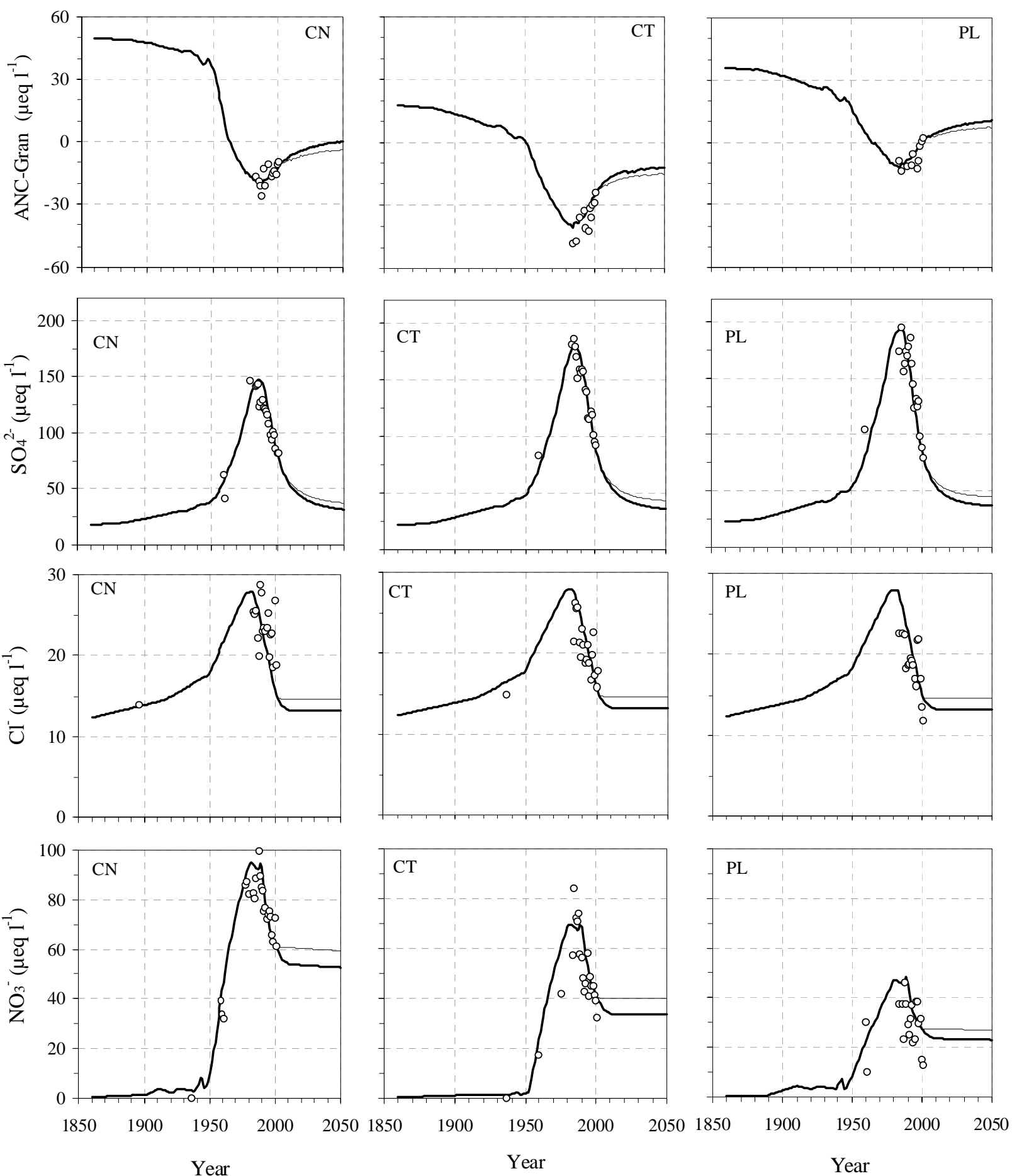

Fig. 3. Measured (open circles) and modelled (lines) trends in major anions in the Bohemian Forest Lakes. Forecasts are based on the 2000 deposition level (thin line) and the decreased $S$ and $N$ deposition proportionally to their emission rate in central Europe according to Gothenburg Protocol (UN-ECE, 1999) (heavy line). ANC-Gran represents measured and/or modelled Gran alkalinity. Lake abbreviations refer to: CN, Cerné; CT, Certovo; and PL, Plešné.

the forest ecosystems from N-limitation to N-saturation and to a decreasing ability to retain $\mathrm{N}$ (Fig. 2). The elevated terrestrial $\mathrm{NO}_{3}^{-}$export may be associated with a decreased ability of the catchments to assimilate N, e.g. due to unfavourable soil conditions for forest growth (extremely low $\mathrm{Ca}$ : Al ratios in soil solutions; see later), or with changes in the mineralisation rate of soil organic $\mathrm{N}$ due to elevated DIN deposition, as has been observed elsewhere (e.g. 
Gundersen et al., 1998a). Thus, the empirical DIN retention within the Bohemian Forest soils (Fig. 2) represents a net difference between the potentially reduced sinks and the elevated internal sources of nitrogen.

The $\mathrm{NO}_{3}^{-}$concentrations in the Bohemian Forest lakes decreased more than the DIN deposition during the 1990s. A similar response of ecosystem export of $\mathrm{NO}_{3}{ }^{-}$to declining DIN deposition was observed in other mountain areas of the Czech Republic (Veselý et al., 2002). To simulate the current lake water concentrations of $\mathrm{NO}_{3}^{-}$, a slight recovery in the ecosystem's ability to retain $\mathrm{N}$ was expected in response to the decline in DIN deposition (Fig. 2).

The prediction of lake water $\mathrm{NO}_{3}^{-}$concentrations was set to the current $\mathrm{N}$ cycling situation within the ecosystems and was based on the assumption that the ecosystem $\mathrm{N}$ retention characteristic would not change (Fig. 2). However, any future changes in the ecosystem ability to immobilise N (e.g. in the vigour of forest microbial activity) can bias the forecasts given in Fig. 3 (see also Norton and Veselý, 2003).

The current characteristics of $\mathrm{NO}_{3}^{-}$leaching from the Bohemian Forest soils fit well the empirical relationships (e.g. Dise and Wright, 1995; Gundersen et al., 1998a,b) which link the $\mathrm{N}$ leaching from European sites to $\mathrm{N}$ deposition, soil C : N ratios, and pH (Kopácek et al., 2001a). Nevertheless, none of these factors can explain fully the observed differences between the catchments and historical changes in $\mathrm{N}$ export from the Bohemian Forest soils during the periods of increasing or decreasing DIN deposition. Modelling of these trends is based here on empirical experience and not on causalities and processes. Although this approach enables a detailed reconstruction of lake water chemistry, it can predict the future changes with only limited significance until the processes involved in $\mathrm{N}$ cycling are better understood.

\section{MODELLED V. OBSERVED LAKE WATER COMPOSITION}

Observed and modelled lake water concentrations of major anions are shown in Fig. 3. Concentrations of $\mathrm{SO}_{4}{ }^{2-}$ and $\mathrm{Cl}^{-}$ paralleled deposition trends, increasing from their respective background concentrations of $18-23$ and $12 \mu \mathrm{eq} \mathrm{l}^{-1}$ to maxima in the 1980s, and then decreasing to the current concentrations of $84-98$ and $13-18 \mu$ eq $1^{-1}$. The modelled trends predicted an additional sharp decrease in $\mathrm{SO}_{4}{ }^{2-}$ concentrations by the late 2010s (Fig. 3). With no additional reduction in $\mathrm{S}$ and $\mathrm{Cl}$ emission in central Europe after 2010,

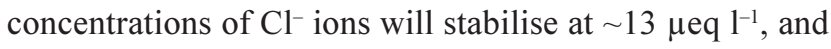
$\mathrm{SO}_{4}{ }^{2-}$ concentrations will decrease slowly to $32-37 \mu \mathrm{eq}{ }^{-1}$ over the next 40 years, approaching new steady state conditions in the soil S pool. Simulated trends in $\mathrm{SO}_{4}{ }^{2-}$ and
$\mathrm{Cl}^{-}$concentrations agree reasonably well with observations both during the acidification advance and retreat.

Simulated trends in ANC (Gran alkalinity) fit the observations reasonably and follow inverse pattern to the trends in strong acid anions (Fig. 3). The modelled lake water ANC values vary between 17 and $49 \mu$ eq $1^{-1}$ in 1860 . Compared to the current situation, the model predicts a relatively rapid additional increase in ANC by the late 2010s, after which ANC concentrations level off at substantially lower than pre-acidification levels. According to these predictions, positive ANC can be expected only in the PL and $\mathrm{CN}$ lakes (Fig. 3).

The changes in concentration of strong acid anions and ANC are partly compensated for by changes in $\mathrm{BC}, \mathrm{H}^{+}$, and $\mathrm{Al}_{\mathrm{i}}^{\mathrm{n}+}$ concentrations (Fig. 4). All the modelled cation concentrations fit the observations during the acidification retreat. The only reliable historical results on cation analyses are those with colorimetric $\mathrm{pH}$ determinations (Procházková and Blažka, 1999). With the exception of slightly higher measured pH in CN Lake in 1936 and 1947, MAGIC also simulates, reasonably, the in-lake $\mathrm{pH}$ decline during the acidification progress. The simulated pre-acidification $\mathrm{pH}$ values vary between 6.0 and 6.7 in 1860 . These values are surprisingly more than one $\mathrm{pH}$ unit higher than diatominferred $\mathrm{pH}$, which indicates a pre-industrial $\mathrm{pH}$ of around 4.7 in CT Lake (Veselý et al., 1993) and 5.0-5.3 in CN lake (Schmidt et al., 1993). Such a difference is atypically high compared to other sites where the MAGIC and diatominferred $\mathrm{pH}$ trends exhibited comparable values (Cumming et al., 1992; Sullivan et al., 1996).

This discrepancy indicates that the processes controlling acidity in small lakes may be more complex than previously thought. The diatom-inferred $\mathrm{pH}$ of the lakes is based almost entirely on non-planktonic (benthic, epilithic, periphytic and metaphytic) species. The actual lake water $\mathrm{pH}$ may be underestimated because: (1) Benthic or epilithic diatoms could grow in tributaries (or at their mouths), which are generally more acidic and have higher $P$ concentrations than lake water (e.g. Kopácek et al., 2001 b,c,d). (2) Periphytic or metaphytic diatoms could grow on macrophytes in littoral zones, also affected by more acidified tributaries. (3) In small lakes, with a high shoreline to area ratio, these diatom sources are relatively more important for the total in-lake diatom production than in larger lakes. Moreover, these diatoms can be more easily transported secondarily to the sediments in the deepest parts of small lakes. Such processes could contribute significantly to the observed prevalence of acidobiontic or acidophilous diatoms in the sediment cores and, therefore, to the underestimation of inferred $\mathrm{pH}$ of the lakes studied.

The modelled concentrations of dissolved $\mathrm{Al}$ (sum of $\mathrm{Al}_{\mathrm{i}}$ 

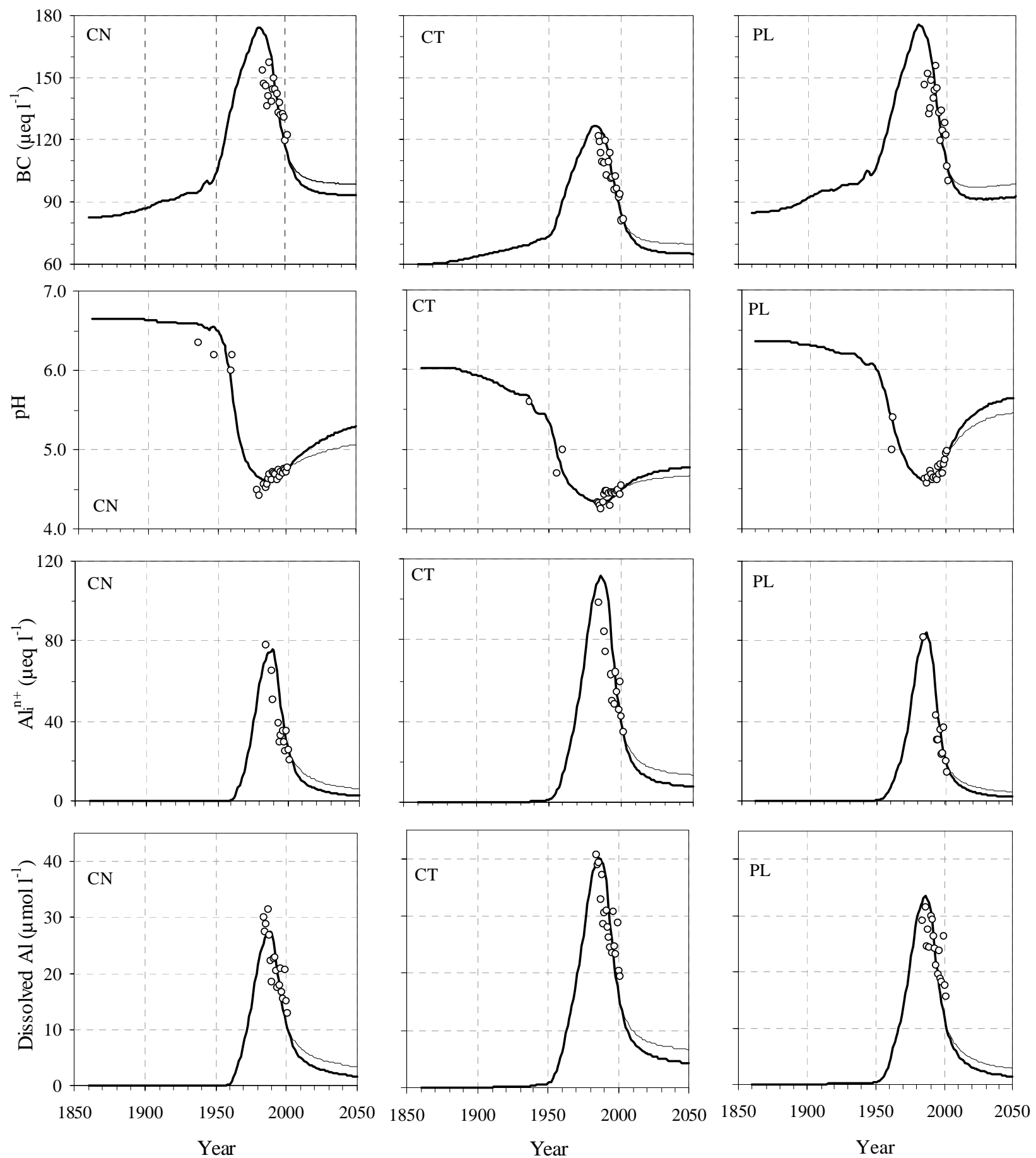

Fig. 4. Measured (open circles) and modelled (lines) trends in major cations in the Bohemian Forest Lakes. Forecasts are based on the 2000 deposition level (thin line) and the decreased $S$ and $N$ deposition proportionally to their emission rate in central Europe according to Gothenburg Protocol (UN-ECE, 1999) (heavy line). Lake abbreviations refer to: CN, Cerné; CT, Certovo; and PL, Plešné.

and $\mathrm{Al}_{\mathrm{o}}$ ) and $\mathrm{Al}_{\mathrm{i}}{ }^{\mathrm{n}+}$ were $<1 \mu$ mol $\mathrm{l}^{-1}$ and $<2 \mu$ eq $\mathrm{l}^{-1}$, respectively, before 1950 and reached their maxima of $27-$ $40 \mu \mathrm{mol} 1^{-1}$ and $75-111 \mu$ eq $1^{-1}$ in the mid-1980s (Fig. 4). The current Al concentrations have declined 50-70\% compared to these maxima. The model predicts a further sharp decline in Al concentrations by 2010, after which the $\mathrm{Al}_{\mathrm{i}}^{\mathrm{n}+}$ concentrations will be comparable to those in the late 1950s $\left(<10 \mu \mathrm{eq} 1^{-1}\right)$. Such a decline in concentrations of the most important toxicant in lake water is promising for the biological recovery of the lakes studied. Biological recovery 
of the lakes, however, is delayed substantially compared to the chemical reversal. Up to the present, increasing numbers of only Ceriodaphnia quadrangula in CN Lake and planktonic rotifers in PL Lake have been observed (Vrba et al., 2003).

Despite the relatively advanced chemical reversal from acidification, all the lakes are still acidic. The changes in relative ionic composition of the lakes (Fig. 5) suggest that bicarbonate was depleted in CN and PL Lakes before the 1960s and in CT Lake even a decade earlier. During the acidification peak, $\mathrm{SO}_{4}{ }^{2-}$ dominated $(55-70 \%)$ the anionic pool and $\mathrm{Al}_{\mathrm{i}}^{\mathrm{n}+}$ was the major cation $(30-40 \%$ of the sum of
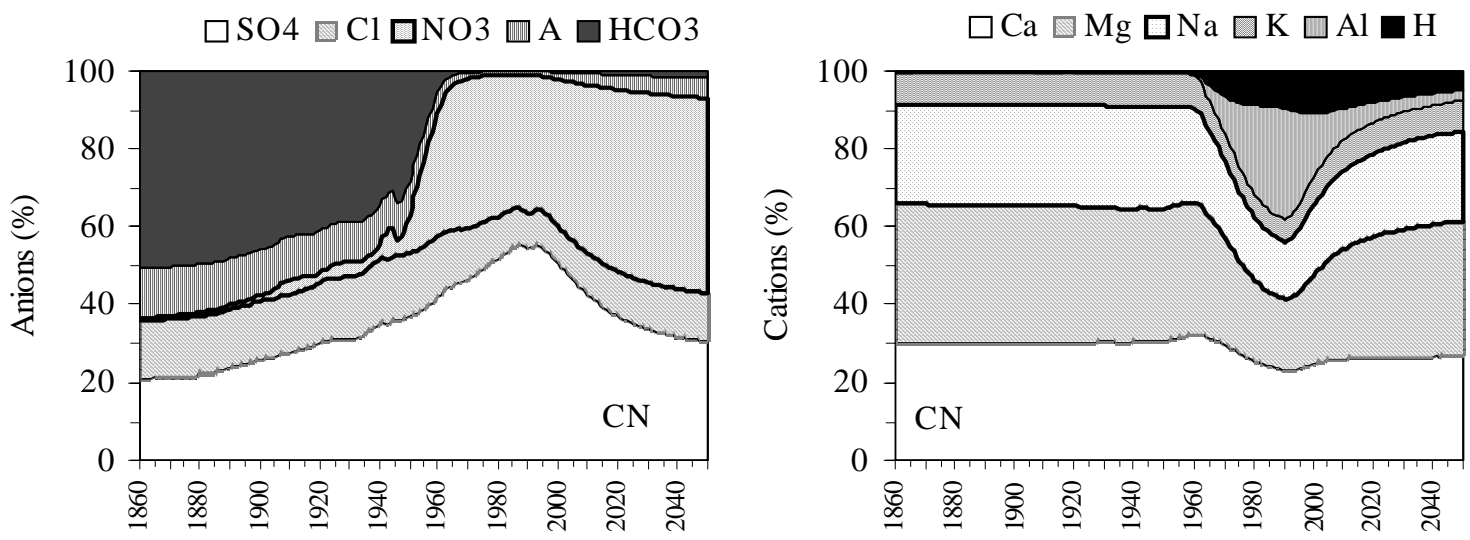

$\square \mathrm{SO} 4 \square \mathrm{Cl} \square \mathrm{NO} 3 \square \mathrm{A} \square \mathrm{HCO} 3$
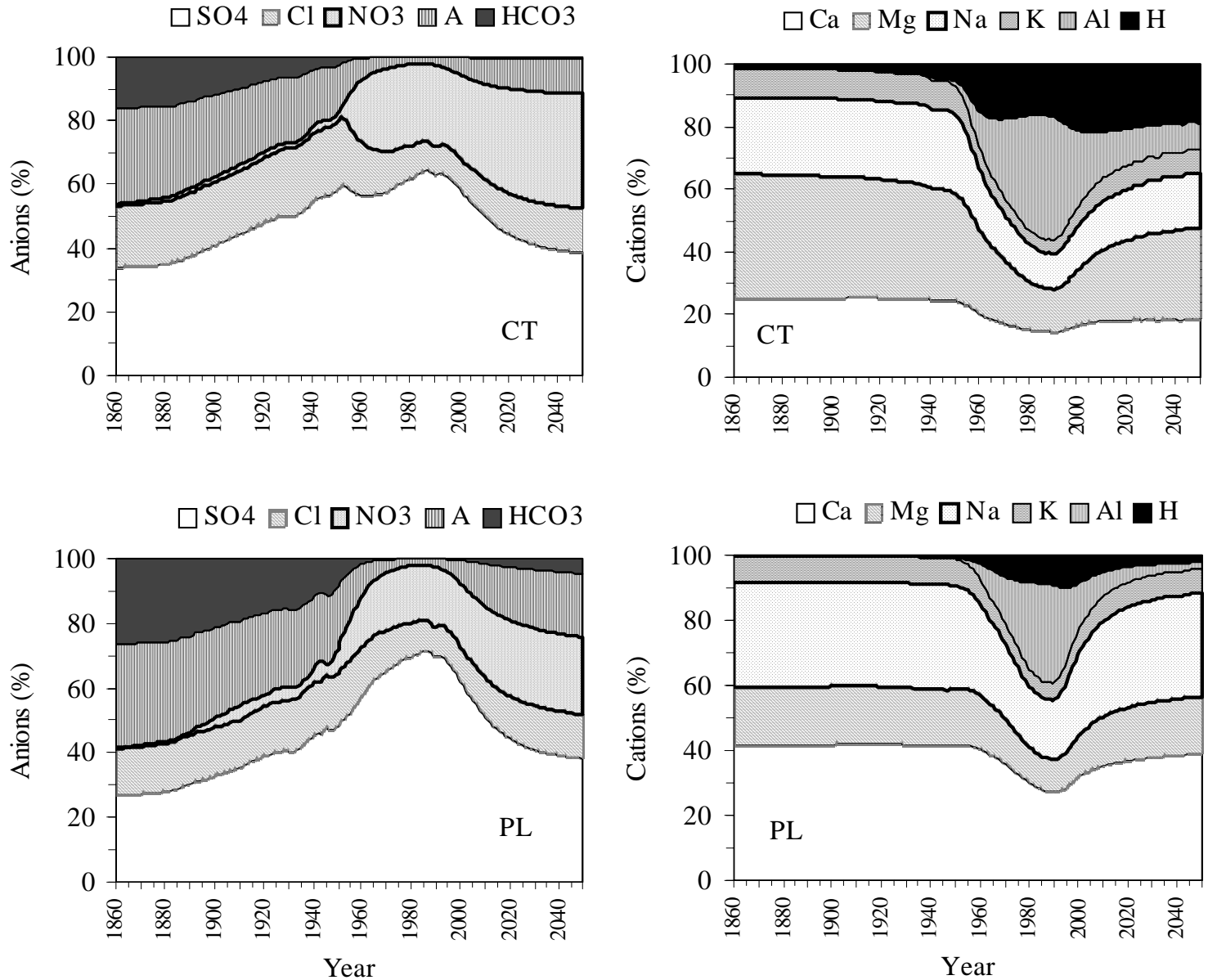

Fig. 5. Relative composition of water in the Bohemian Forest Lakes as simulated by MAGIC model. The 2000-2050 forecasts is based on $S$ and $N$ deposition level proportional to central Europe emission rate according to Gothenburg Protocol (UN-ECE, 1999). Lake abbreviations refer to: CN, Cerné; CT, Certovo; and PL, Plešné. 
cations). The modelled changes predict the increasing importance of $\mathrm{NO}_{3}^{-}$to become the dominant anion in $\mathrm{CN}$ and CT Lakes around 2050, and a partial recovery of the bicarbonate buffering system in CN and PL Lakes. These changes will be accompanied by a rapidly decreasing importance in the $\mathrm{Al}_{\mathrm{i}}^{\mathrm{n}+}$ contribution and an increasing contribution of $\mathrm{BC}$ to the cationic pool. A pronounced increase in $\mathrm{pH}$ will probably occur in PL Lake only (Figs. 3 and 4).

\section{TRENDS IN SOIL CHEMISTRY}

Among the lakes studied, the chemical composition of soil and soil solutions differ significantly (Fig. 6). The modelled pre-acidification soil base saturation is highest (27\%) in PL Lake and lowest (11\%) in CT Lake. Similarly, loss of BC from the soil cation-exchange sites is most pronounced in PL Lake while relatively flat in CT Lake. Both the current and 'Gothenburg' scenarios of the future emission rates of $\mathrm{S}$ and $\mathrm{N}$ compounds in central Europe result in similar trends in base saturation of the Bohemian Forest soils (Fig. 6). These predictions suggest a gradual accumulation of $\mathrm{BC}$ in the CN and PL soils, resulting in a slow increase in their base saturation. Even in 2050, however, base saturation of the $\mathrm{CN}$ and PL soils will be $\sim 40 \%$ lower than levels in 1860 . No increase in base saturation is predicted for the CT soils (Fig. 6), suggesting that the decreases in emissions expected by the Gothenburg protocol will only stop the depletion of the exchangeable $\mathrm{BC}$ pool, but will be insufficient for its recovery. Similar results are also evident from other very strongly acidified forest sites (e.g., Hruška et al., 2002).

A low molar $\mathrm{Ca}$ to $\mathrm{Al}$ ratio in soil solutions $(\mathrm{Ca}: \mathrm{Al}<1)$ is another ecologically important parameter, indicating possible adverse impacts of soil chemistry on tree growth and tissue nutrient concentrations (e.g. Puhe and Ulrich, 2001). The modelled $\mathrm{Ca}: \mathrm{Al}$ values are $>1$ only in the $\mathrm{CN}$ and PL soils and only until the 1950s and 1970s, respectively, while lower values obtain for CT soils throughout the whole 1860-2050 period (Fig. 6). Similarly to base saturation of soils, the trend in soil solution $\mathrm{Ca}$ : Al ratio, most pronounced in the PL catchment and flattest in the CT catchment, exhibits signs of a future increase only in the $\mathrm{PL}$ and $\mathrm{CN}$ soils.
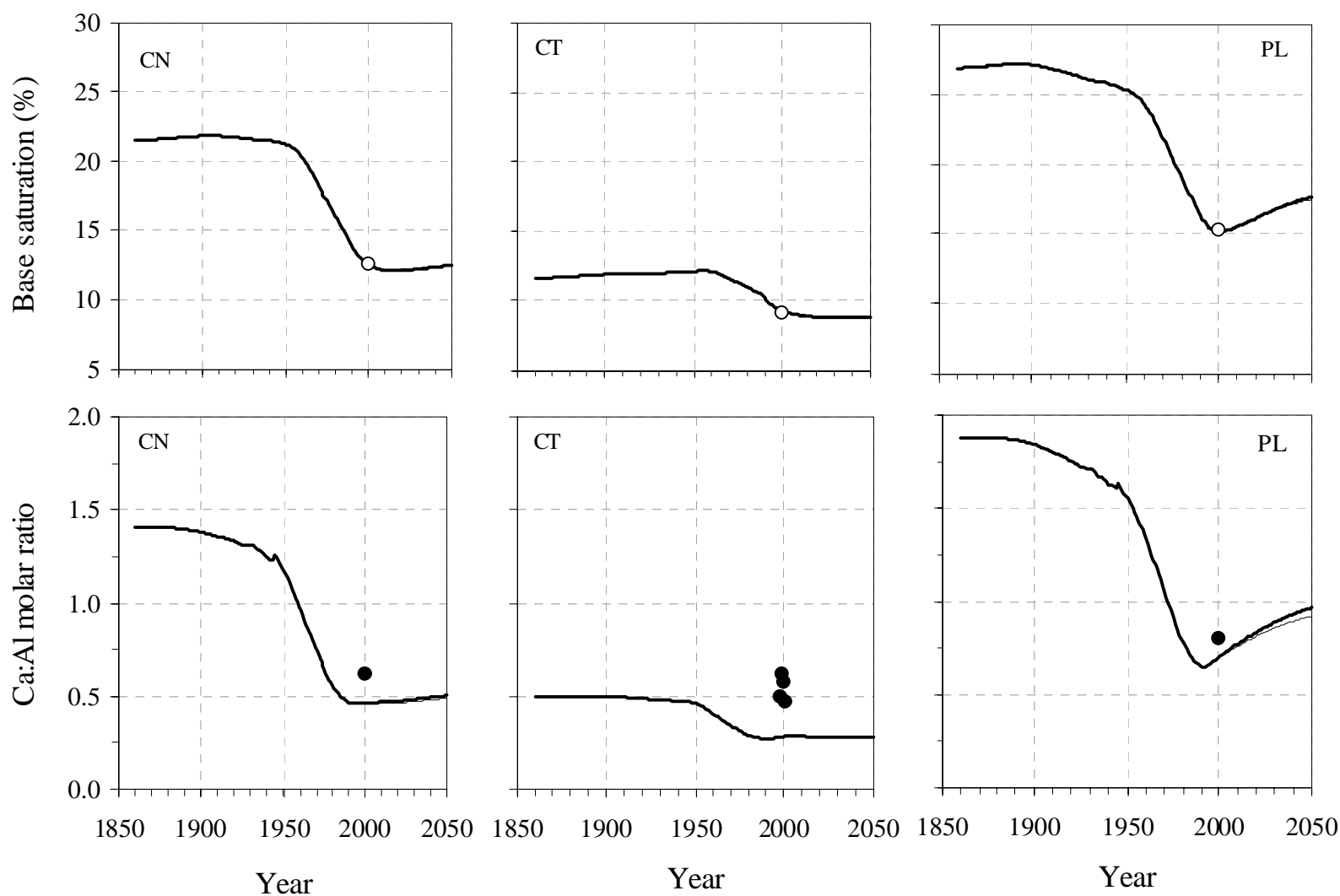

Fig. 6. Measured (open circles) and modelled (lines) trends in soil chemistry in the Bohemian Forest Lakes. Forecasts are based on the 2000 deposition level (thin line) and the decreased $S$ and $N$ deposition proportionally to their emission rate in central Europe according to Gothenburg Protocol (UN-ECE, 1999) (heavy line). Black circles in lower panel represent the Ca:Al ratios in lake tributaries (annual discharge weighted means). Lake abbreviations refer to: CN, Cerné; CT, Certovo; and PL, Plešné. 
Soil solutions were not analysed in this study. Instead, the modelled data have been compared with annual discharge weighted mean values of $\mathrm{Ca}$ : Al ratios in the lake tributaries (Kopácek et al., 2001b,c,d). These values (black points in Fig. 6), are higher than the Ca:Al ratios in soil solutions due to a partial contribution of overflow to the runoff without percolating through the mineral soil horizons. Even the Ca:Al ratios in lake tributaries, however, show a pattern similar to the modelled data, being higher in the $\mathrm{CN}$ and PL than in CT tributaries.

According to the MAGIC simulation for the next five decades, the desirable reversal of $\mathrm{Ca}$ : Al ratios in soil solutions toward $\sim 1$ can be expected only in the PL catchment (situated on granite) but will remain $<0.5$ in the $\mathrm{CT}$ and $\mathrm{CN}$ catchments, underlain with mica schist. This difference is due to (i) the lower depletion of the soil exchangeable Ca pools in the PL than $\mathrm{CN}$ and $\mathrm{CT}$ catchments (Table 1), (ii) the two-fold higher content of $\mathrm{Ca}$ in granite than in mica schist (0.11 vs. $\sim 0.06 \mathrm{~mol} \mathrm{~kg}^{-1}$; Kopácek et al., 2002 b,c) and (iii) significantly higher repletion of the soil pools of $\mathrm{Ca}$ by weathering in the PL catchment (Table 3 ).

\section{LAKE TO LAKE VARIATIONS IN THE REGION}

Atmospheric deposition of $\mathrm{S}$ and oxidised $\mathrm{N}$ compounds (Fig. 1) is the major driving force governing the in-lake concentrations of major ions, which exhibit similar trends in all lakes (Figs. 3 and 4). Despite the same deposition history and comparable morphological characteristics of the ecosystems studied (Table 1), the chemical composition of lake waters differs significantly. These differences are associated predominantly with bedrock composition, land use history (affecting both soil and water composition), and in-lake processes (associated with nutrient loading) as follows:

(1) Soils, weathering, and land-use history-Concentrations of $\mathrm{SO}_{4}{ }^{2-}$ and $\mathrm{NO}_{3}{ }^{-}$differ among the lakes studied, but lakes with lower $\mathrm{NO}_{3}{ }^{-}$concentrations have higher $\mathrm{SO}_{4}{ }^{2-}$, which results in comparable concentrations of strong acid anions (e.g. 255-275 $\mu$ eq $\mathrm{l}^{-1}$ during the acidification peak, Fig. 3). The ecosystems differ in the way this acidity is compensated for with cations. While the responses of the $\mathrm{CN}$ and PL catchment-lake ecosystems are comparable despite the different bedrock, CT Lake (with bedrock similar to $\mathrm{CN}$ Lake) is most acidified, has lowest concentrations of $\mathrm{BC}$, and highest $\mathrm{Al}_{i}^{\mathrm{n}+}$ concentrations (Fig. 4). Moreover, the modelled $\mathrm{pH}$ exhibits a continuously decreasing trend in CT Lake from the late 19th century to the 1980s (Fig. 4). The different response of the CT ecosystem to neutralise acid loads resulted from a substantially lower base saturation of soils (Fig. 6).
The difference in soil composition between the geographically adjacent CT and CN Lakes may well result from lower weathering rates and different land-use history. The CT catchment was deforested more than the $\mathrm{CN}$ catchment in the first half of the 18th century and was used as pasture for about 100 years. Pasturing and burning of bushes probably contributed to a continual decrease in the base saturation of the catchment soils. Another depletion of the CT soil pools of BC was probably associated with the subsequent draining and re-afforestation of the CT catchment with spruce in the middle 19th century. This process led to the accumulation of $\mathrm{BC}$ from the soil exchangeable pools in the rapidly growing forest. Moreover, repletion of the soil $\mathrm{BC}$ pool from weathering was less effective in the CT than the $\mathrm{CN}$ catchment, because part of the CT bedrock is quartzite.

The less rapid acidification-derived changes in $\mathrm{CN}$ than in CT Lake could also be attributed partly to return-water pumping by a power station into CN Lake during the 19301975 period (water from the lake was partly mixed with less acidified river water). However, the similar patterns of the modelled and measured $\mathrm{pH}$ trends in $\mathrm{CN}$ and unaffected PL Lake (Fig. 4) suggest that this land-use aspect had probably only a limited effect on the acid-base chemistry of CN Lake.

(2) In-lake processes - The most pronounced difference in the chemistry of the lakes studied was associated with $\mathrm{NO}_{3}^{-}$ concentration, which was lowest in PL Lake (Fig. 3). Part of this difference was due to the higher ability of the PL catchment to assimilate N. Consequently, PL Lake had a lower input of DIN compared to the other two lakes. In the 2000 hydrological year, the total DIN input (via tributaries and direct atmospheric deposition) was 780 and 1030 meq $\mathrm{m}^{-2} \mathrm{yr}^{-1}$ (given on a lake surface area basis) in PL and CN Lakes, respectively (Kopácek et al., 2001c,d). In-lake removal of $\mathrm{NO}_{3}^{-}$, calculated according to Kelly et al. (1987) with a mass transfer coefficient for colder lakes ( $5 \mathrm{~m} \mathrm{yr}^{-1}$; Curtis et al., 1998), suggests a 29-35\% internal reduction of these DIN loads. The primary mechanism of this DIN reduction is $\mathrm{NO}_{3}^{-}$diffusion into the sediments followed by denitrification under anoxic conditions. The measured internal reduction of DIN was $28 \%, 33 \%$, and $50 \%$ in $\mathrm{CN}$, CT, and PL Lakes, respectively, in the 2000 hydrological year (Kopácek et al., 2001b,c,d). While the empirical and estimated values are well comparable in CN and CT Lakes, a substantially higher in-lake reduction in the DIN loads was observed in PL Lake. The latter lake received $\sim$ fivefold higher loads of phosphorus (predominantly in the form of soluble reactive $\mathrm{P}$ ), leading to higher primary production. The resulting assimilation of $\mathrm{N}$ by algae and their 
sedimentation represents another significant sink for DIN in PL Lake, which is also evident from the higher $\mathrm{N}$ sedimentation rate in this lake (Table 1).

\section{Conclusions}

The chemistry of Bohemian Forest lakes has exhibited significant changes toward chemical reversal from atmospheric acidification since the late 1980s. The MAGIC model forecasts further advancement in this process for about the next two decades. Sulphate leaching and BC export from soils should decline to their levels at the beginning of the 20th century, and $\mathrm{Al}_{i}^{\mathrm{nt}}$ concentrations in lake water to their levels in the 1950s. Only in two of the three lakes studied will these changes be sufficient for the reestablishment of the bicarbonate buffering system and $\mathrm{pH}$ increase over the unit of 5. These lakes (CN and PL) have less depleted soil $\mathrm{BC}$ pools, which can partly recover in the 2000-2050 period. In contrast, the more acidified CT catchment-lake ecosystem will recover more slowly. Until 2050 (and probably even several decades longer), soil base saturation will not increase in the $\mathrm{CT}$ catchment and the lake water bicarbonate buffering system will not be reestablished.

While the measured trends in $\mathrm{pH}$ and $\mathrm{ANC}, \mathrm{SO}_{4}{ }^{2-}, \mathrm{Cl}^{-}$, $\mathrm{Al}_{\mathrm{i}}^{\mathrm{n}+}$, and $\mathrm{BC}$ concentrations are simulated reasonably by MAGIC 7, historical simulations of $\mathrm{NO}_{3}^{-}$are speculative due to the changing ability of the terrestrial parts of ecosystems studied to assimilate nitrogen, which is not associated with significant changes in the soil $\mathrm{C}: \mathrm{N}$ ratios. Without more detailed knowledge of current $\mathrm{N}$-cycling within the forest soils and potential mechanisms that can affect the terrestrial immobilisation of $\mathrm{N}$, future predictions of $\mathrm{NO}_{3}^{-}$leaching are hypothetical. Undoubtedly, $\mathrm{NO}_{3}^{-}$will become the dominant strong acid anion in the Bohemian Forest lakes over the next five decades and the major carrier of BC from soils. Climatic, chemical or physiological (e.g. forest die-off) changes, however, can affect the future terrestrial $\mathrm{NO}_{3}{ }^{-}$export significantly and invalidate the prognoses based on the current situation.

\section{Acknowledgement}

The primary data on soil, water, and deposition chemistry were collected within projects supported by the Grant Agency of the Czech Republic (project No 206/00/0063), Institutional Research Plan ASCR No. Z 6017912, and MSM 123100004, and were evaluated within and in co-operation with the Environment Projects of European Commission: RECOVER:2010 (Project No. EVK1-CT-1999-00018) and EMERGE (EVK1-CT-1999-00032), respectively.

\section{References}

Alewell, C., 1998. Investigating sulphate sorption and desorption of acid forest soils with special consideration of soil structure. Z. Pflanzenernähr. Bodenk., 161, 73-80.

Alewell, C., Manderscheid, B., Meesenburg, H. and Bittersohl, J., 2000. Is acidification still an ecological threat? Nature, 407, 856-857.

Berge, E., 1997. Transboundary air pollution in Europe, Part 1, EMEP MSC-W Report 1/97, Norwegian Meteorological Institute, Oslo, Norway. 108pp .

Barrett, K., Schaug, J., Bartonova, A., Semb, A., Hjellbrekke, A.G. and Hanssen, J.E., 2000. A contribution from CCC to the reevaluation of the observed trends in sulphur and nitrogen in Europe 1978-1998: CCC Report 7/2000, Norwegian Institute for Air Research, Kjeller, Norway. 205pp .

Browne, B.A. and Driscoll, C.T., 1993. pH-dependent binding of aluminum by a fulvic acid. Environ. Sci. Technol., 27, 915922.

Cosby, B.J., Wright, R.F., Hornberger, G.M. and Galloway, J.N., 1985. Modelling the effects of acid deposition: estimation of long term water quality responses in a small forested catchment. Water Resour. Res., 21, 1591-1601.

Cosby, B.J., Ferrier, R.C., Jenkins, A., Emmett, B.A., Wright, R.F. and Tietema, A., 1997. Modelling the ecosystem effects of nitrogen deposition at the catchment scale: model of ecosystem retention and loss of inorganic nitrogen (MERLIN). Hydrol. Earth Syst. Sci., 1, 137-158.

Cosby, B.J., Ferrier, R.C., Jenkins, A. and Wright, R.F., 2001. Modelling the effects of acid deposition: refinements, adjustments and inclusion of nitrogen dynamics in the MAGIC model. Hydrol. Earth Syst. Sci., 5, 499-517.

Cumming, B.F., Smol, J.P., Kingston, J.C., Charles, D.F., Birks, H.J.B., Camburn, K.E., Dixit, S.S., Uutala, A.J. and Selle, A.R., 1992. How much acidification has occurred in Adirondack region lakes (New York, USA) since preindustrial times. Can. J. Fisheries Aquat. Sci. 49, 128-141.

Curtis, C.J., Allott, T.E.H., Reynolds, B. and Harriman, R., 1998. The prediction of nitrate leaching with the first-order acidity balance (FAB) model for upland catchment in Great Britain. Water Air Soil Pollut., 105, 205-215.

Dise, N.B. and Wright, R.F., 1995. Nitrogen leaching from European forests in relation to nitrogen deposition. Forest Ecol. Manage., 71, 153-161.

Dise, N.B., Matzer, E. and Gundersen, P., 1998. Synthesis of nitrogen pools and fluxes from European forest ecosystems. Water Air Soil Pollut., 105, 143-154.

Driscoll, C. T., 1984. A procedure for the fractionation of aqueous aluminum in dilute acidic waters. Int. J. Environ. Anal. Chem., 16, 267-284.

Evans, C.D., Cullen, J.M., Alewell, C., Kopácek, J., Marchetto, A., Moldan, F., Prechtel, A., Rogora, M., Veselý, J. and Wright, R., 2001. Recovery from acidification in European surface waters. Hydrol. Earth Syst. Sci., 5, 283-297.

Fott, J., Pražáková, M., Stuchlík, E. and Stuchlíková, Z., 1994. Acidification of lakes in Sumava (Bohemia) and in the Tatra Mountains (Slovakia). Hydrobiologia, 274, 37-47.

Gundersen, P., Emmett, B.A., Kjonaas, O.J., Koopmans, C.J. and Tietema, A., 1998a. Impact of nitrogen deposition on nitrogen cycling in forests: a synthesis of NITREX data. Forest Ecol. Manage., 71, 143-151.

Gundersen, P., Callesen, I. and de Vries, W., 1998b. Nitrate leaching in forest ecosystems is related to forest floor $\mathrm{C} / \mathrm{N}$ ratios. Environ. Pollut., 102, 403-407. 
Hruška, J., Kopácek, J., Hlavatý, T. and Hošek, J., 2000. Trend of atmospheric deposition of acidifying compounds at Certovo Lake, south-western Czech Republic (1992-1999). Silva Gabreta, 4, 71-86.

Hruška, J., Moldan, F. and Krám, P., 2002. Recovery from acidification in central Europe - observed and predicted changes of soil and streamwater chemistry in the Lysina catchment, Czech Republic. Environ. Pollut., 120, 261-274.

Jírovec, O. and Jírovcová, M., 1937. Chemistry of the Bohemian Forest lakes. Vestník k. c. spol. nauk, Tr. II (13), 1-21 (in Czech).

Kelly, C.A. and Rudd, J.W.M., 1984. Epilimnetic sulfate reduction and its relationship to lake acidification. Biogeochemistry, 1, 63-77.

Kelly, C.A., Rudd, J.W.M., Hesslein, R.H., Schindler, D.W., Dillon, P.J., Driscoll, C.T., Gherini, S.A. and Hecky, R.E., 1987. Prediction of biological acid neutralisation in acid-sensitive lakes. Biogeochemistry, 3, 129-140.

Kopácek, J., Hejzlar, J., Stuchlík, E., Fott, J. and Veselý, J., 1998. Reversibility of acidification of mountain lakes after reduction in nitrogen and sulphur emissions in Central Europe. Limnol. Oceanogr., 43, 357-361.

Kopácek, J., Veselý, J. and Stuchlík, E., 2001a. Sulphur and nitrogen fluxes and budgets in the Bohemian Forest and Tatra Mountains during the Industrial Revolution (1850-2000). Hydrol. Earth Syst. Sci., 5, 391-405.

Kopácek, J., Hejzlar, J., Kana, J. and Porcal, P., 2001b. Element budgets in three Bohemian Forest lakes and their watersheds in the 2000 hydrological year: I. Certovo Lake. Silva Gabreta, 6, $35-52$.

Kopácek, J., Hejzlar, J., Kana, J., Porcal, P., Pšenáková, P. and Vrba, J., 2001c. Element budgets in three Bohemian Forest lakes and their watersheds in the 2000 hydrological year: II. Cerné Lake. Silva Gabreta, 6, 53-72.

Kopácek, J., Hejzlar, J. Kana, J. and Porcal, P., 2001d. Element budgets in three Bohemian Forest lakes and their watersheds in the 2000 hydrological year: III. Plešné Lake. Silva Gabreta, 6, 73-86.

Kopácek, J., Stuchlík, E., Veselý, J., Schaumburg, J., Anderson, I.C., Fott, J., Hejzlar, J. and Vrba, J., 2002a. Hysteresis in reversal of Central European mountain lakes from atmospheric acidification. Water Air Soil Pollut: Focus 2, 91-114.

Kopácek, J., Kana, J., Santrucková, H., Porcal, P., Hejzlar J., Picek, T. and Veselý, J., 2002b. Physical, chemical, and biochemical characteristics of soils in watersheds of the Bohemian Forest lakes: I. Plešné Lake. Silva Gabreta, 8, 43-62.

Kopácek, J., Kana, J., Santrucková, H., Porcal, P., Hejzlar J., Picek, T., Simek, M. and Veselý, J., 2002c. Physical, chemical, and biochemical characteristics of soils in watersheds of the Bohemian Forest lakes: II. Certovo and Cerné Lakes. Silva Gabreta, 8, 63-93.

Kopácek, J., Cosby, B.J., Majer, V., Stuchlík, E. and Veselý, J., 2003. Modelling reversibility of Central European mountain lakes from acidification: Part II - The Tatra Mountains. Hydrol. Earth Syst. Sci., 7, 510-524.

Lovett, G.M., 1992. Atmospheric deposition and canopy interactions of nitrogen. In: Atmospheric Deposition and Forest Nutrient Cycling, D.W. Johnson and S.E. Lindberg (Eds.), Ecological Studies 91, Springer, New York, USA. 152-166.

Nordstrom, D.K., 1982. The effect of sulphate on aluminium concentrations in natural waters: some stability relations in the system $\mathrm{Al}_{2} \mathrm{O}_{3}-\mathrm{SO}_{3}-\mathrm{H}_{2} \mathrm{O}$ at $298 \mathrm{~K}$. Geochim. Cosmochim. Acta, 46, 681-692.

Nordstrom, D.K. and Howard, M.M., 1996. Aqueous equilibrium data for mononuclear aluminum species. In: The environmental chemistry of aluminum, G. Sposito (Ed.), Lewis Publishers, Chelsea, UK. 39-80.
Norton, S.A. and Veselý, J., 2003. Acidification and Acid Rain. In: Environmental Geochemistry B. Sherwood Lollar (Ed.), Vol.9, Treatise on Geochemistry, Elsevier, New York, USA. (in press).

Novák, M., Bottrell, S.H., Fottová, D., Buzek, F., Groscheová, H. and Žák, K., 1996. Sulphur isotope signals in forest soils of Central Europe along an air pollution gradient. Environ. Sci. Technol., 30, 3473-3476.

Prechtel, A., Alewell, C., Armbruster, M., Bittersohl, J., Cullen, J., Evans, C., Helliwell, R., Kopácek, J., Marchetto, A., Matzner, E., Meesenburg, H., Moldan, F., Moritz, K., Veselý, J. and Wright, R.F., 2001. Response of sulphur dynamics in European catchments to decreasing sulphate deposition. Hydrol. Earth Syst. Sci., 5, 311-324.

Procházková, L., 1959. Bestimmung der Nitrate im Wasser. Z. anal. Chem., 167, 254-260 (in German).

Procházková, L. and Blažka, P., 1999. Chemistry and biology of the Bohemian Forest lakes in the early 1960s. Silva Gabreta, 3, 65-72 (in Czech).

Puhe, J. and Ulrich, B., 2001. Global Climate Change and Human Impacts on Forest Ecosystems. Ecological Studies 143, Springer, Berlin, Germany. 592pp.

Schmidt, R., Arzet, K., Facher, E., Fott, J., Irlweck, K., Reháková, Z., Rose, N., Straškrabová, V. and Veselý, J., 1993. Acidification of Bohemian lakes. Recent trends and historical development. Ost-West Program Report GZ 45.168/1-276(b), Mondsee, Austria. 86pp.

Stoddard, J.L., 1994. Long-term changes in watershed retention of nitrogen. In: Environmental Chemistry of Lakes and Reservoirs, L.A. Baker (Ed.), American Chemical Society, Advances in Chemistry No 237, Washington D.C., USA. 223284.

Stumm, W. and Morgan, J.J., 1981. Aquatic Chemistry. Wiley, New York, USA.

Sullivan, T.J., Cosby, B.J., Driscoll, C.T., Charles, D.F. and Hemond, H.F., 1996. Influence of organic acids on model projections of lake acidification. Water Air Soil Pollut., 91, 271282.

Torssander, P. and Mörth, C.-M., 1998. Sulphur dynamics in the Roof experiment at Lake Gardsjön deduced from sulphur and oxygen isotope ratios in sulphate. In: Experimental Reversal of Acid Rain Effects. The Gardsjön Roof Project, H. Hultberg and R. Skeffington (Eds.), Wiley, Chichester, UK. 185-206.

UN-ECE, 1999. Strategies and Policies for Air Pollution Abatement. Economic Commission for Europe (ECE.EB.AIR/ 65), Convention on Long-Range Transboundary Air Pollution, United Nations, New York and Geneva.

Veselý, J., 1994. Investigation of the nature of the Sumava lakes: a review. Casopis Národního Muzea, Praha, Rada prírodovedná, 163, 103-120.

Veselý, J. and Majer, V., 1992. The major importance of nitrate increase for the acidification of two lakes in Bohemia. Doc. Ist. Ital. Idrobiol., 32, 83-92.

Veselý, J., Almquist-Jacobson, H., Miller, L.M., Norton, S.A., Appleby, P., Dixit, A.S. and Smol, J.P., 1993. The history and impact of air pollution at Certovo Lake, southwestern Czech Republic. J. Paleolimnol., 8, 211-231.

Veselý, J., 1998. Changes in vegetation of the Cerné Lake area inferred from pollen analysis of lake sediment: period between 3400 BC and 1600 AD. Silva Gabreta, 2, 141-153.

Veselý, J., Hruška, J., Norton, S.A. and Johnson, C.E., 1998a. Trends in water chemistry of acidified Bohemian lakes from 1984 to 1995: I. Major solutes. Water Air Soil Pollut., 108, 107127. 
Veselý, J., Hruška, J. and Norton, S.A., 1998b. Trends in the chemistry of acidified Bohemian lakes from 1984 to 1995: II. Trace elements and aluminum. Water Air Soil Pollut., 108, 425443.

Veselý, J., Majer, V. and Norton, S.A., 2002. Heterogeneous response of central European streams to decreased acidic atmospheric deposition. Environ. Pollut. 120, 275-281.
Vrba, J., Kopácek, J., Fott, J., Kohout, L., Nedbalová, L., Pražáková, M., Soldán, T. and Schaumburg, J., 2003. Longterm studies (1871-2000) on acidification and recovery of lakes in the Bohemian Forest (central Europe). Sci. Total Environ., 310, 73-85.

Wright, R.F., Emmett, B.A. and Jenkins, A., 1998. Acid deposition, land-use change and global change: MAGIC 7 model applied to Aber, UK (NITREX project) and Risdalsheia, Norway (RAIN and CLIMEX projects). Hydrol. Earth Syst. Sci., 2, 385-397. 